\title{
SATISFACTION, PURCHASING BEHAVIOR, AND CUSTOMER LOYALTY OF BUTIK EMAS LOGAM MULIA
}

\author{
Fakhri Reza*)1, Ujang Sumarwan ${ }^{2}$, and Hartoyo ${ }^{3}$ \\ ${ }^{1,3}$ Business School, IPB University, Indonesia, 16151 \\ ${ }^{2}$ Department of Family and Consumer Sciences, Faculty of Human Ecology, IPB \\ University, Indonesia, 16680 \\ *Corresponding author: sumarwan@apps.ipb.ac.id
}

\begin{abstract}
This research study aims to highlights the factors of customer loyalty based on satisfaction, consumer buying behavior at Butik Emas Logam Mulia (BELM) Pulogadung. Using the SERVQUAL services model to analyze quality of services by descriptive statistics method. This study was conducted using 200 respondents selected by purposive. Tangible, empathy, responsiveness, reliability, and assurance (Service Quality Dimensions) were the variables considered for this study. The research found that reliability and responsiveness (not empathy, tangibility, and assurance) impact consumer satisfaction which increases the frequency of purchasing. It explains, a negative relationship between satisfaction and loyalty intensions. Furthermore, both loyalty and satisfaction effects weaken with increased prior consumption experiences, related on organizational issues. Thus, when the customers invest in satisfaction, managers should consider their individual marginal impacts on loyalty and distinguish between consumers with reference to their prior consumption experiences. The managerial implication in marketing strategies to increase customer loyalty, consumer satisfaction is directly related to provide fast, precise, and friendly services in accordance with established service standards. Moreover, the research study concludes that image of a service provider, loyalty of consumers, consumer expectations, perceived value, perceived quality and the way complains are handled are very important factors that determine consumer loyalty levels.
\end{abstract}

Keywords: consumers, loyalty, satisfaction, SERVQUAL.

\begin{abstract}
Abstrak
Penelitian ini bertujuan mengidentifikasi faktor-faktor yang mempengaruhi kepuasan, perilaku pembelian, dan loyalitas pelanggan di Butik Emas Logam Mulia Pulogadung. Penelitian ini menggunakan model SERVQUAL untuk menganalisis kualitas pelayanan dengan pendekatan deskriptif kuantitatif. Jumlah sampel sebanyak 200 responden yang dipilih secara purposive sampling. Variabel penelitian ini diantaranya adalah dimensi pelayanan tangible, empathy, responsiveness, reliability, dan assurance. Penelitian ini menemukan bahwa reliability dan responsiveness (not empathy, tangibility, dan assurance) menjadi faktor pada kepuasan konsumen yang meningkatkan frekuensi pembelian. Hal ini menjelaskan hubungan negatif antara kepuasan dan loyalitas. Selain itu, loyalitas dan kepuasan melemah dengan meningkatnya pengalaman konsumsi sebelumnya pada masalah organisasi. Sehingga manajer harus mempertimbangkan
\end{abstract}


dampak marginal individu pada loyalitas dan membedakan antara konsumen berdasarkan pengalaman konsumsinya. Implikasi manajerial dalam strategi marketing adalah untuk meningkatkan kesetiaan, kepuasan pelanggan yang secara langsung akan memberikan pelayanan yang cepat, tepat, dan ramah sesuai dengan standar layanan yang ditetapkan. Selain itu, penelitian ini menyimpulkan bahwa citra penyedia layanan, loyalitas konsumen, harapan konsumen, nilai yang dirasakan, kualitas yang dirasakan dan cara pengaduan ditangani adalah faktor yang sangat penting yang menentukan tingkat loyalitas konsumen.

Kata kunci: konsumen, loyalitas, kepuasan, SERVQUAL

\section{Introduction}

One motive for investing is to get financial benefits in the future Moosa (2000). According to Baur and Lucey (2010), gold investment is in second place after investment in the real sector. The similarity of gold investment with the real sector which is an advantage is that both have tangible value, intrinsic value, and there is inherent or innate value. Gold is a profitable long-term investment. This is due to the price of gold, which tends to continue to increase both in the local market and the world market - and not affected by the existence of inflation (zero inflation). This is as said by Tyson (2011) that gold is valued as a means to increase the value and amount of assets owned.

Today, delivery of high-quality service is the key to success in service industries. In the present era of intense competition, monitoring and improving service quality is highly essential for developing efficiency and business volume (Meesalaa \& Paul, 2016). Knowledge about these aspects does, however, remain theoretically and empirically ambiguous. Although there is a presumption that efforts to strengthen satisfaction will aid loyalty as well as suggest that the association between satisfaction and loyalty is not as strong as generally assumed (Carlson, O'Cass, \& Ahrholdt, 2015). For example, (Brown, Smith, \& Assaker, 2016) explain that the structural model indicated of sport involvement and place attachment influenced revisit intentions, but this was not the case for event satisfaction. Level of satisfaction was considered to be a discrete experience without implications for future behavior towards the destination. To understand the role of trust and satisfaction play in sustainable business practices, we interpret the sustainable consumption process and the conflicting attitudes consumers have about sustainable loyalty.

Then identify the role of trust and satisfaction for the firm customer relationship in the supply chain is discussed with the widely accepted service quality (SERVQUAL) dimensions - tangibility, empathy, reliability, responsiveness, and assurance - could be studied to understand their impact on the important quality outcomes such as consumers' satisfaction, particularly in the developing countries.

In Indonesia, the purpose of someone invest is to get profits in the future. One of the investment's type is gold. Gold precious metal is a safe investment choice and provides competitive returns (Anita, 2014). Gunawan and Wirawati (2013) prove that in the long - term investment in gold, precious metal instruments is considered more profitable than investing in stocks. According to (Baur \& Lucey, 2008), gold investment is second only to investment in the real sector. Good service quality will create 
satisfaction for customers. Customers who are satisfied with the product or service they receive will compare the services obtained. If the customer is satisfied, the customer will remain to buy at the same place and will even recommend the place to others.

Service quality besides being able to satisfy its customers, can also increase customer loyalty, which will lead to increased company profits. This is based on previous research conducted by (Rust, Zahorik, \& Keiningham, 1995); (Annisa, 2014); (Panjaitan, 2016); (Nugraheni \& Kirana, 2018); (Rizq, Djamaludin, \& Nurhadryani, 2018); (Arthur, Asmara, \& Simanjuntak, 2019). Then continued by the research of (Batalden et al., 1992) which shows the relationship between customer satisfaction to hospital profitability and research that tests the relationship of customer satisfaction to customer retention in retail banking. Other research (Hallowell, 1996) also shows that customer satisfaction, customer loyalty, and profitability are related to each other.

We assume that satisfaction with a firm's service incorporates cognitive elements, emotional elements, or both (for an overview). Satisfaction is generally defined as a post - choice evaluative judgment (Westbrook \& Oliver, 1991). This evaluation varies along a continuum from "dissatisfied" to "satisfied". Until now, to the best of our knowledge, no study has empirically tested the link between retailer personality and consumers' satisfaction with that retailer. Satisfaction refers to an emotional state resulting from a consumer evaluation of a service provided by a company and the response to it (Westbrook, 1987). Therefore, consumer satisfaction is principally determined by the quality of their experience and communication with the service provider (Crosby, Evans, \& Cowles, 1990). It is also influenced by the price and quality of the service, and by individual characteristics such as age and gender (Zeithaml, Parasuraman, \& Berry, 2006). Moreover, satisfaction has positive effects on consumer loyalty (Gronholdt, Martensen, \& Kristensen, 2010; Homburg, Stierl, \& Bornemann, 2013; Lee, Lee, \& Feick, 2001)

Several factors that can influence purchasing decisions, such as the factors stated by (Kotler \& Keller, 2016) include 1) Cultural factors; 2) Social factors; 3)Personal factors, and 4) Psychological factors consist of motivation, perception, learning, and memory. The consumer decision process will consist of a phase of the need for recognition, information search, alternative evaluation, purchasing, and customer satisfaction (Aviliani et al., 2011).

Handoyo and Setiawan (2015) examined the influence of demographic characteristics such as age, income level, gender, and level of education on consumer complaining behavior at the Yamaha Diponegoro Denpasar service shop. The result is that the demographic character has a significant effect on consumer complaining behavior at the Yamaha Diponegoro Denpasar service shop. A few of service quality has an effect on customer satisfaction, among others, conducted by (Akhtar \& Zaheer, 2014), conduct research on service quality dimensions of Islamic banks: a scale development approach.

The results showed that tangibility with different demographic variables such as age, gender, country, profession, and educational qualifications had insignificant differences while satisfaction of joint and professional customers had significant temporary differences along with age, gender, state qualifications, and education - no significant difference. The level of community satisfaction is measured through five dimensions of service quality, namely reliability, responsiveness, assurance, empathy, and tangibles. With the path analysis model, the results show the dimensions that have the most influence on community satisfaction, namely empathy and tangible. Heviandri, 
Sumarwan, and Retnaningsih (2009) examined the analysis of customer satisfaction with services at Soekarno Hatta airport, as well as its implications for the City Check-In Terminal (CCT) marketing strategy in Jakarta. In this study analyzed how the segmentation of aviation consumer demographics obtained managerial implications to see who are potential customers of CCT service users.

Mardatilla, Kusyanti, and Aryadita (2017) examined the effect of service quality on customer satisfaction, trust, and loyalty in e-commerce. The results of this study indicate that the five dimensions of service quality have no effect on satisfaction, satisfaction has a positive and significant effect on trust, but word-of-mouth has no effect on goals, trust has a positive and significant effect on goals but has no effect on word-of-mouth, and the last hypothesis of the local customer dimension of word-ofmouth has a positive and significant effect on objectives. Djamaluddin, Sumarwan, and Mahardikawati (2009) show the results of research that factors that have a real relationship with the level of consumer satisfaction herbal medicine are marriage status, education level, and family income level per month. This can be seen from the statistical test using the chi-square test $(\mathrm{p}<0.05)$.

Currently, there are quite several places to invest in gold starting from banks, pawnshops, gold shops, and one of them is in Butik Emas Logam Mulia (BELM) PT. Antam Tbk. Logam Mulia Refinery Business Unit (UBPP LM) which provides various brands and types of gold bars. UBPP LM which is engaged in the main processing and refining services of precious metals such as gold, silver, and platinum. LM is a precious metal processing and refining factory that has refining (smelter), manufacturing, assaying, and trading services. In terms of gold bar UBPP LM has become a producer leader and market leader through the Precious Metal brand (LM) which is currently a trusted brand in terms of grade quality and product quality.

Through UBPP LM's core business trading, it has marketed its products both domestically and abroad and has gained local and international recognition. At present, the number of Branch of BELM is in 15 locations, one of which is in Pulogadung. In the retail industry customer satisfaction is a goal in business as well as UBPP LM business that emphasizes customer satisfaction. Customer needs are not only limited to satisfaction with the product or service but also satisfaction with the services provided. Prevailing UBPP LM has become the only gold bullion producer in Indonesia that has international accreditation which means a fulcrum for the global precious metals market, it sets the standard for the purity, shape, origin, manner and where they are traded from the London Bullion Market Association (LBMA). However, the role of service is also mandatory to be prioritized.

UBPP LM just starting to focus on the retail industry with the development of its marketing distribution channels through the BELM which was established in 2013 where the quality of its services still needs to be developed. Since BELM established, UBPP LM also participated in improving the quality of its service by evaluating services through customer satisfaction surveys.

Although the level of satisfaction increases but the analytical method used is considered to be less specific and less profound to measure BELM customer satisfaction, an additionals analysis methods are needed to be able to measure the quality of each service contact and its effect on customer satisfaction. Furthermore, it also measures how it affects loyalty and buying behavior at BELM Pulogadung.

Based on the description above, the purpose of the research is to identify the factors that influence satisfaction, purchasing behavior, and customer loyalty in BELM Pulogadung. 


\section{Methods}

The research study uses a quantitative descriptive approach through a survey. A survey is one type of descriptive research which is a research design to find out about the reasons, the process carried out by a research subject (Sumarwan, 2014). The data used are primary. Primary data is data that is obtained or collected directly by researchers from the source. Data retrieval of this research study was conducted in October 2018 located at the company's store which called Butik Emas Logam Mulia (BELM) (Gold Boutique of Logam Mulia) located in the office of PT. Antam Unit Bisnis Pengolahan dan Pemurnian (UBPP) Logam Mulia (Precious Metal Refinery Business Unit), having its address at Pemuda Street No. 1 Pulogadung, East Jakarta, Indonesia 13010.

The research study was conducted with the total number of samples of 200 respondents. The sampling technique used in this study was a non-probability sampling technique, that is sampling techniques without opportunities (Sumarwan 2014). The determination of samples is based on purposive sampling technique which targeted customers that have made purchases at least one transaction in the past one year during 2018. The purpose is to have a better experience of assessing and evaluating the types of service contracts obtained from the previous transactions. The data collecting technique used in this research study was by direct interviewing that given face to face to customers on the structured questionnaire one of the types of question is based on Likert scale with five scale from strongly dissatisfied to strongly satisfied.

The theory used in this research is SERVQUAL service quality, which consists of five variable dimensions, such as tangible, empathy, responsiveness, reliability, and assurance (Zeithaml et al., 1990). The overall series of models were analyzed using the PLS SEM method with Smart PLS 3 software. SEM consists of 2 parts, the latent variable model and the measurement model. The SEM PLS approach does not assume certain distributed data, can be nominal, ordinal, interval or ratio (Ghozali, 2008).

The procedures of this study are:

1. Defining the variables (construct and indicators) based on the theory of the previous study, i.e. servqual (service quality), satisfaction, and loyalty. Construct is a variable that cannot be observed directly so it will be measured by indicators or observed variables.

2. Developing a path diagram using the defined variables. There are two models which will be made in Structural Equation Modeling, which are measurement model and structural model. 


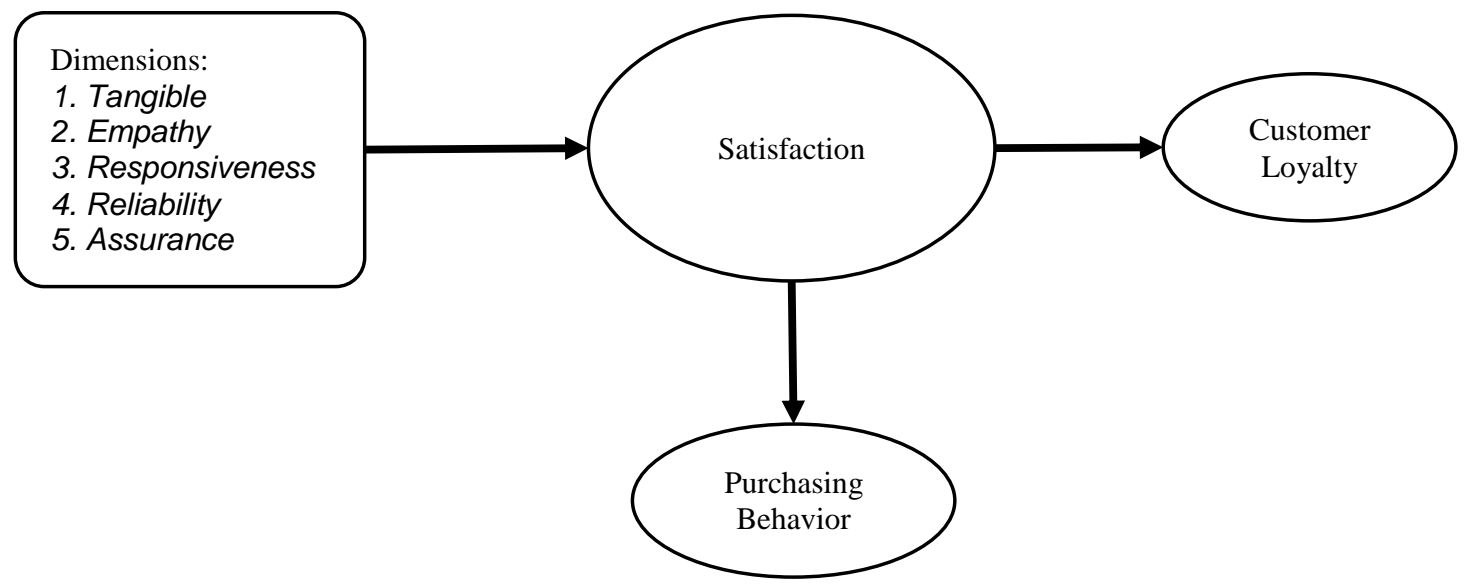

Figure 1 Conceptual thinking

Hypotheses:

1. H1: Perceived quality \& service provided (SERVQUAL) of ANTAM positively influences customers' satisfaction.

2. H2: Customers satisfaction (SERVQUAL) of ANTAM positively influences customers' behavior.

3. H2: Customers satisfaction (SERVQUAL) of ANTAM positively influences customers' loyalty.

Table 1 The construct and indicator variables

\begin{tabular}{|c|c|c|c|c|c|}
\hline $\begin{array}{c}\text { Type of } \\
\text { Variables }\end{array}$ & $\begin{array}{l}\text { Construct } \\
\text { Variables }\end{array}$ & $\begin{array}{l}\text { Notation for } \\
\text { construct }\end{array}$ & Indicator Variables & $\begin{array}{l}\text { Item } \\
\text { Name }\end{array}$ & $\begin{array}{l}\text { Notation } \\
\text { for } \\
\text { Indicator }\end{array}$ \\
\hline \multirow[t]{3}{*}{ Exogen } & Tangible & $\xi_{1}$ & Location & Q1 & $x_{1}$ \\
\hline & & & Officer Appearance & $\mathrm{Q} 2$ & $x_{2}$ \\
\hline & & & Entertainment Facilities & Q3 & $x_{3}$ \\
\hline \multirow[t]{3}{*}{ Exogen } & Empathy & $\xi_{2}$ & Hospitality security & Q4 & $x_{4}$ \\
\hline & & & $\begin{array}{l}\text { The hospitality of CS } \\
\text { officers }\end{array}$ & Q5 & $x_{5}$ \\
\hline & & & Courtesy CS officers & Q6 & $x_{6}$ \\
\hline \multirow[t]{3}{*}{ Exogen } & $\begin{array}{l}\text { Responsivene } \\
\text { ss }\end{array}$ & $\xi_{3}$ & $\begin{array}{l}\text { Speed of response of } \\
\text { security officers }\end{array}$ & Q7 & $x_{7}$ \\
\hline & & & $\begin{array}{l}\text { Feedback on helping } \\
\text { customers by CS }\end{array}$ & Q8 & $x_{8}$ \\
\hline & & & Clarity of Information & Q9 & $x_{9}$ \\
\hline \multirow[t]{4}{*}{ Exogen } & Reliability & $\xi_{4}$ & $\begin{array}{l}\text { Coincidentally } \\
\text { customers problems } \\
\text { solving }\end{array}$ & Q10 & $x_{10}$ \\
\hline & & & $\begin{array}{l}\text { Suitability of the weight } \\
\text { of the product } \\
\text { purchased }\end{array}$ & Q11 & $x_{11}$ \\
\hline & & & Failed Product & Q12 & $x_{12}$ \\
\hline & & & $\begin{array}{l}\text { Antam's reputation as a } \\
\text { state-owned company }\end{array}$ & Q13 & $x_{13}$ \\
\hline \multirow[t]{2}{*}{ Exogen } & Assurance & $\xi_{5}$ & Sense of Security & Q14 & $x_{14}$ \\
\hline & & & $\begin{array}{l}\text { Certificate of Product } \\
\text { Quality }\end{array}$ & Q15 & $x_{15}$ \\
\hline Endogen & Satisfaction & $\eta_{1}$ & Frequency of purchases & Q16 & $y l$ \\
\hline
\end{tabular}


Reza, Sumarwan, \& Hartoyo / Journal of Consumer Sciences, 2019, Vol. 04, No. 02

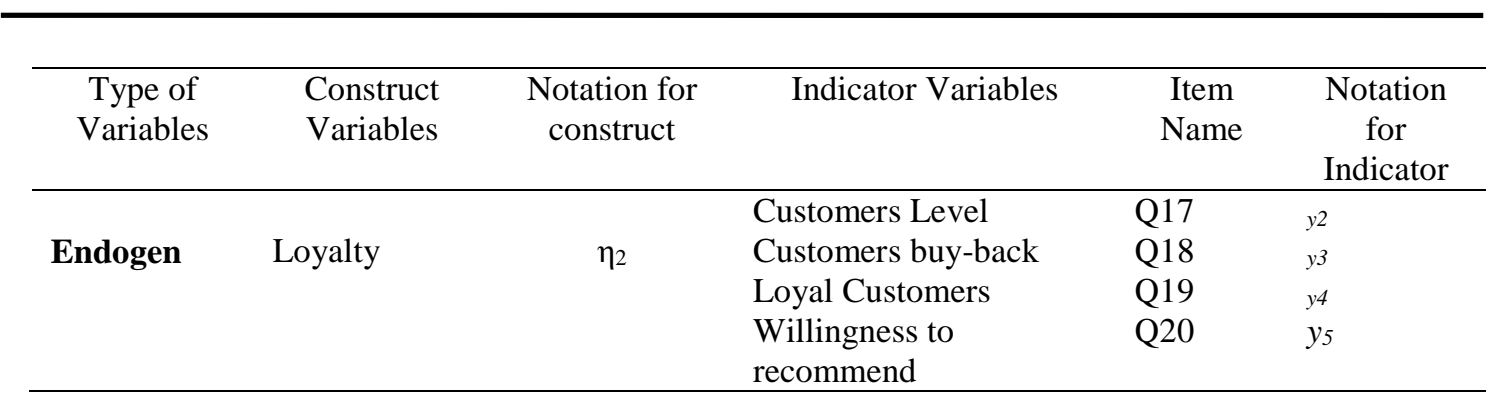

\section{Findings}

\section{Demographic and Characteristic of the Respondent}

The result presents the demographics of the sample, which are male. A great majority of the participants are from 18-37 age group (65.5\%), and they mostly hold a bachelor's degree. To provide an overview of the characteristics of the BELM customers in the Pulogadung branch the research will be explained quantitatively in the form of percentages related to age, expenditure, and education. The first characteristic is that the age grouped into three groups, namely young (18 - 37 years) as many as 65.5 percents, adults (38 - 53 years) as many as 33 percent and elderly (over 53 years) as many as 1.5 percents. The second characteristic is that education is classified into three groups, namely high school education and below it as many as 18.5 percents, Diploma as many as 17.5 percent, and scholars as much as 64 percent. The third characteristic is expenditure classified into three groups, namely the upper group (SES A) with expenditure above 5 million rupiahs per month as many as 81.5 percents, upper-middleclass (SES B) with expenditure of 3-5 million rupiahs per month 18.5 percent. There are no customers from the lower middle class (SES C) with expenditures under 3 million rupiah per month.

\section{SERVQUAL}

The satisfaction level of each SERVQUAL dimension, such as Tangible is 4.18; Empathy is 4.32; Responsiveness is 4.24; Reliability is 4.36; Assurance is 4.35. Service quality in each SERVQUAL dimension is measured by variable indicators as in Table 2.

Table 2 Service quality

\begin{tabular}{lc}
\hline Dimension & Satisfaction \\
\hline Tangible & 4.18 \\
Location & 4.14 \\
Officer appearance & 4.28 \\
Entertainment facilities & 4.13 \\
\hline Empathy & 4.32 \\
Hospitality security & 4.30 \\
Hospitality of CS officers & 4.32 \\
Courtesy CS officers & 4.35 \\
\hline Responsiveness & 4.24 \\
Speed of response of security officers & 4.21 \\
Speed of response of CS officers & 4.16 \\
Information clarity & 4.36 \\
\hline Reliability & 4.36
\end{tabular}




\begin{tabular}{lc}
\hline Dimension & Satisfaction \\
\hline Problem solving accuracy & 4.21 \\
Suitability of weigth & 4.39 \\
No flaws & 4.47 \\
Assurance & 4.35 \\
Reputation & 4.17 \\
Secure & 4.39 \\
Certificate & 4.49 \\
\hline
\end{tabular}

The dimension that is considered to be the most satisfactory is Reliability measured by the accuracy of handling the problem, the suitability of the weight of the product, and there are no defects in the product. The second is the dimension of Assurance as measured by Antam's reputation as a state-owned company, certifying product quality, and feeling secure when getting services. This means that these two dimensions need to be the company's attention to be maintained because it gives high satisfaction to customers while the dimensions that are considered the lowest satisfaction are tangible which is measured by the ease of finding the location, appearance of officers and the availability of entertainment facilities while waiting in line. This means that this dimension needs attention from the company to improve the quality of its services.

Overall the satisfaction indicators in the TERRA dimension, the highest level of satisfaction is the existence of a product quality certificate in the Assurance Dimension with a satisfaction level of 4.48. Second is the absence of defects in the product in the Reliability Dimension with a satisfaction level of 4.47. Both of these indicators need to be maintained by the company because they provide high satisfaction to customers while the lowest parameter level of satisfaction is the availability of entertainment facilities while waiting in line with a satisfaction level of 4.13 and ease of finding a boutique location with a satisfaction level of 4.14 .

The level of satisfaction in the tangible dimension is 4.18, which means that the customer is satisfied with the quality of service in the tangible dimension. However, it should be noted that the tangible dimension has the lowest level of satisfaction compared to other dimensions. This is due to the low level of satisfaction on the indicator of the ease of finding the location and availability of entertainment facilities while waiting for the queue.

Satisfaction level on the empathy dimension is 4.32 , which means that customers feel very satisfied with the quality of service in the empathy dimension. The indicator that is considered the most satisfying is the courtesy of CS officers when communicating to serve customers with a satisfaction level of 4.35. Then the hospitality of CS officers when serving customers with a satisfaction level of 4.32. The last indicator of security staff friendliness with a satisfaction level of 4.30.

The satisfaction level of the responsiveness dimension is 4.24 , which means that the customer is satisfied with the quality of service on the responsiveness dimension. The indicator with the highest level of satisfaction is information clarity, which is equal to 4.36. Then the speed of response of security officers in helping customers with satisfaction levels of 4.21. Finally, the speed of response of CS officers in serving customers with a satisfaction level of 4.16 .

The level of satisfaction of the reliability dimension is 4.36 , which means that customers feel very satisfied with the quality of service in the reliability dimension. The highest indicator of satisfaction is that there is no defect with a satisfaction level of 4.47. 
Then the weight suitability with a satisfaction level of 4.39 and the last accuracy of problem-solving with a satisfaction level of 4.21.

The satisfaction level of Assurance dimension is 4.35, which means that the customer is very satisfied with the quality of service in the assurance dimension. The indicator that was considered the most satisfactory was the existence of a product quality certificate with a satisfaction level of 4.49. Then the feeling of security when getting service with a satisfaction level of 4.39 and Antam's last reputation as a stateowned company with a satisfaction level of 4.17.

\section{Customer Satisfaction}

The BELM Pulogadung, customer satisfaction level, is 4.29 , which means that the customer is satisfied with the service at BELM Pulogadung. The categories of customer satisfaction are grouped as follows:

$\varepsilon=\frac{n-1}{n}$

$1.0-1.8:$ Dissatisfied

$1.9-2.6$ : Dissatisfaction

$2.7-3.4$ : Quite Satisfied

3.4 - 4.2: Satisfied

4.3 - 5.0: Very Satisfied

\section{Purchasing Behavior}

Most of The BELM branch of Pulogadung customers buy gold more than once a year. At least two times (39.5\%), some even more than five times (23.0\%). Almost all for investment purposes $(99.5 \%)$. The majority of BELM customers in Pulogadung Branch have become customers for more than one year (72.0\%)

\section{Customer Loyalty}

BELM Pulogadung's Customer Satisfaction Rate is 4.40, which means that customers are very loyal to BELM Pulogadung. An indicator of loyalty is seen by customers most likely to repurchase gold at Antam BELM if there is an opportunity with a value of 4.44, still choosing BELM as a place to purchase gold with a value of 4.39 , willing to recommend BELM to others as a place to purchase gold with a value of 4.37 .

\section{Results}

\section{Reliability and Validity Construct}

Ensuring that there are no problems related to measurement, first of all in evaluating the outer model is to test the reliability and validity of the model. This test is carried out using Cronbach's Alpha indicators ( $>0.6)$, composite reliability $(>0.7)$, and expected Average Variance Extracted (AVE)> 0.5. Seen in Table 3 the Cronbach Alpha values are all constructs $>0.6$, which means the model is reliable. The value of Composite Reliability is above 0.7 , which means reliability is high. It was also seen that the AVE values were all above 0.5 . This means that all indicators in the model are valid and reliable. 
Table 3 Construct reliability and validity

\begin{tabular}{lccc}
\hline \multicolumn{1}{c}{ Variable } & $\begin{array}{c}\text { Cronbach's } \\
\text { Alpha }\end{array}$ & $\begin{array}{c}\text { Composite } \\
\text { Reliability }\end{array}$ & $\begin{array}{c}\text { Average Variance } \\
\text { Extracted (AVE) }\end{array}$ \\
\hline Customer Satisfaction (X) & 0.832 & 0.880 & 0.556 \\
Tangible (x1) & 0.815 & 0.888 & 0.726 \\
Empathy (x2) & 0.870 & 0.918 & 0.788 \\
Responsiveness (x3) & 0.816 & 0.892 & 0.734 \\
Reliability (x4) & 0.706 & 0.830 & 0.625 \\
Assurance (x5) & 0.822 & 0.878 & 0.711 \\
Purchasing behavior (y1) & 0.801 & 0.908 & 0.832 \\
Customer Loyalty (y2) & 0.751 & 0.854 & 0.662 \\
\hline
\end{tabular}

\section{Influential Factor Analyses of Satisfaction, Purchasing Behavior and Customer Loyalty}

Outer Model Analysis

Outer Model Analysis shown in Figure 2 Outer Model specifies the relationship between latent variables and their indicators, or it can be said that the outer model defines how each indicator relates to its latent variables. Test performed on the outer model:

a. Convergent Validity. Convergent validity value is the value of loading factors on latent variables with their indicators. Expected value $>0.7$. For the first study, the allowable value is between 0.5-0.6. (Ghozali, 2008)

b. Discriminant Validity. This value is a value of cross loading factor that is useful to determine whether the construct has an adequate discriminant by comparing the loading value to the intended construct must be greater than the value of loading with another construct.

c. Composite Reliability. Data that has a composite reliability $>0.7$ sounds high reliability.

d. Average Variance Extracted (AVE). Expected AVE value $>0.5$.

e. Cronbach Alpha. Reliability test was strengthened with Cronbach Alpha, expected value $>0.6$ for all constructs. 


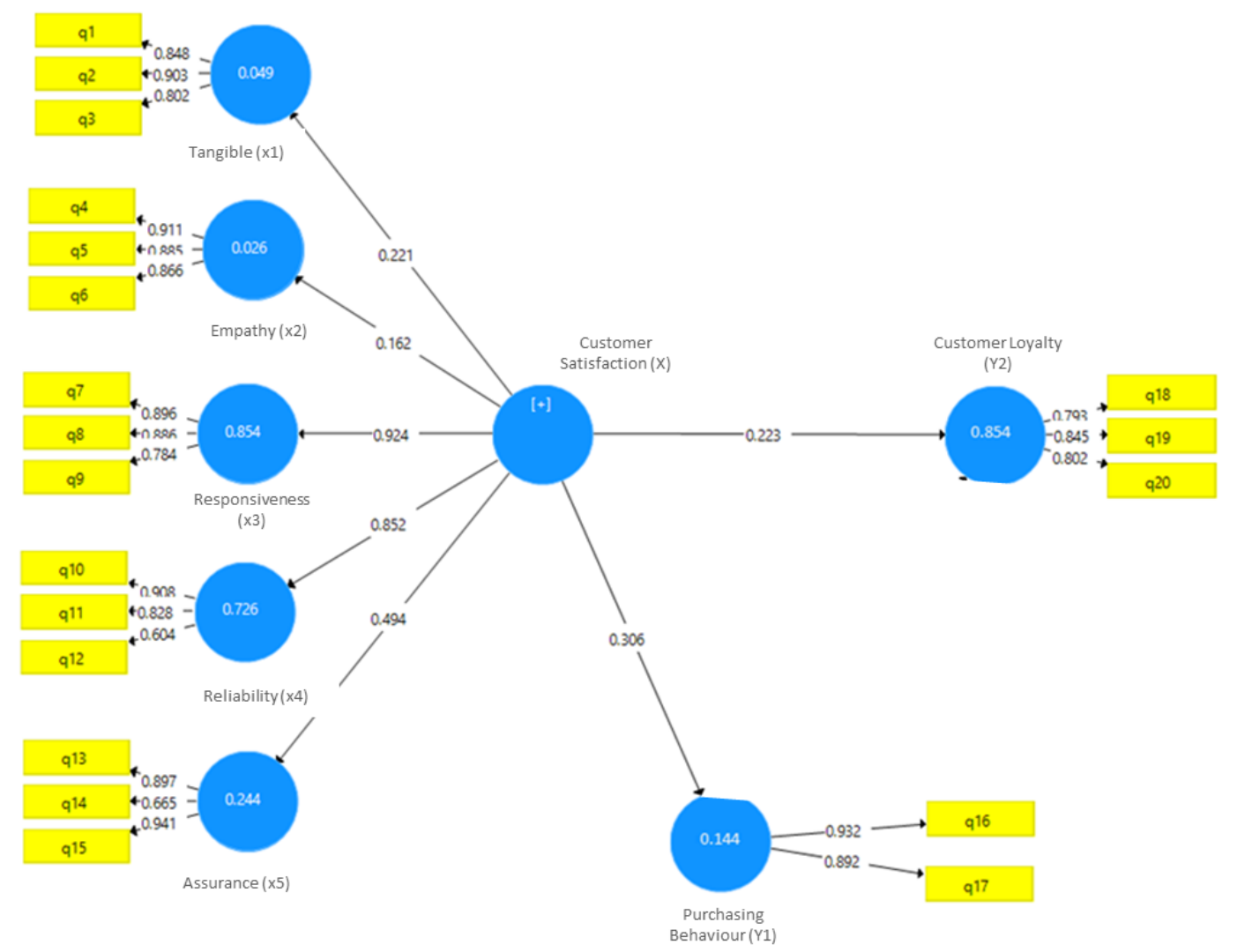

Figure 2 Outer model

Table 4 shows the value of loading factors for all indicators above 0.5 it means these indicators can be interpreted as valid. Also, the calculation results of the t-value are greater than 1.96, then it can be interpreted that all indicators are significantly influential. All indicators of below have a loading factor value ranging from 0.6 - 1.0 which means that there is no problem of convergence validity on the model being tested.

Table 4 Loading factor and t-value model variables

\begin{tabular}{|c|c|c|c|c|}
\hline Variables & Indicator & $\begin{array}{l}\text { Loading } \\
\text { Factor }\end{array}$ & Nilai-t & Result \\
\hline \multirow[t]{3}{*}{ Tangible (x1) } & The Ease of finding location (q1) & 0.848 & 15.187 & valid \\
\hline & Officer appearance (q2) & 0.903 & 11.902 & valid \\
\hline & $\begin{array}{l}\text { Availability of entertainment facilities } \\
\text { while waiting for the queue (q3) }\end{array}$ & 0.802 & 8.211 & valid \\
\hline \multirow[t]{3}{*}{ Empathy (x2) } & $\begin{array}{l}\text { The hospitality of security officers provides } \\
\text { instructions to customers (q4) }\end{array}$ & 0.911 & 7.056 & valid \\
\hline & $\begin{array}{l}\text { The hospitality of CS officers in } \\
\text { understanding customer difficulties (q5) }\end{array}$ & 0.885 & 5.424 & valid \\
\hline & $\begin{array}{l}\text { Courtesy of CS when communicating in } \\
\text { understanding customer difficulties ( } q 6 \text { ) }\end{array}$ & 0.866 & 4.977 & valid \\
\hline \multirow[t]{2}{*}{$\begin{array}{l}\text { Responsiveness } \\
\text { (x3) }\end{array}$} & $\begin{array}{l}\text { Security officer feedback speed in helping } \\
\text { customers (q7) }\end{array}$ & 0.896 & 52.455 & valid \\
\hline & $\begin{array}{l}\text { CS feedback speed in helping customers } \\
\text { (q8) }\end{array}$ & 0.886 & 41.389 & valid \\
\hline
\end{tabular}


Reza, Sumarwan, \& Hartoyo / Journal of Consumer Sciences, 2019, Vol. 04, No. 02

\begin{tabular}{|c|c|c|c|c|}
\hline Variables & Indicator & $\begin{array}{l}\text { Loading } \\
\text { Factor }\end{array}$ & Nilai-t & Result \\
\hline & $\begin{array}{l}\text { Clarity of information provided by officers } \\
\text { (q9) }\end{array}$ & 0.784 & 33.405 & valid \\
\hline \multirow[t]{3}{*}{ Reliability (x4) } & $\begin{array}{l}\text { Accuracy in handling customer problems } \\
\text { (q10) }\end{array}$ & 0.908 & 116.345 & valid \\
\hline & $\begin{array}{l}\text { Compliance with the weight of the product } \\
\text { purchased (q11) }\end{array}$ & 0.828 & 24.835 & valid \\
\hline & There are no product defects (q12) & 0.604 & 7.915 & valid \\
\hline \multirow[t]{3}{*}{ Assurance (x5) } & $\begin{array}{l}\text { Antam's reputation as a state-owned } \\
\text { company (q13) }\end{array}$ & 0.897 & 39.933 & valid \\
\hline & Feeling safe when getting service (q14) & 0.665 & 9.444 & valid \\
\hline & A product quality certificate (q15) & 0.941 & 98.273 & valid \\
\hline \multirow{2}{*}{$\begin{array}{l}\text { Purchasing } \\
\text { behavior (Y1) }\end{array}$} & Frequency of purchase & 0.932 & 64.372 & valid \\
\hline & Long-time to become customer & 0.892 & 30.357 & valid \\
\hline \multirow{3}{*}{$\begin{array}{l}\text { Customer loyalty } \\
\text { (Y2) }\end{array}$} & Repurchase & 0.793 & 14.224 & valid \\
\hline & Keep purchase & 0.845 & 21.936 & valid \\
\hline & Willingness to recommend & 0.802 & 15.989 & valid \\
\hline
\end{tabular}

\section{Inner Model Analysis}

Evaluate the inner model by looking from $R^{2}, Q^{2}$ dan $G o F$. The result shows that the constructed variable purchasing behavior (y1) is explained by customer satisfaction (X) of 0.144 or 14.4 percent. While customer loyalty (Y2) explained customer satisfaction (X) and purchasing behavior (Y1) of 0.854 or 85.4 percent. The R2 value of 0.144 is categorized as weak, while 0.854 is categorized as strong (Chin, 1998). Next, for testing the inner model, a Q2 value of 0.87 ( $>0)$ or the relevant model is used to predict.

To calculate Q2 the formula can be used:

$$
\begin{aligned}
& Q^{2}=1-\left(1-R 1^{2}\right)\left(1-R 1^{2}\right) \\
& \mathrm{Q}^{2}=1-(1-0.144)(1-0.854) \\
& \mathrm{Q}^{2}=0.875
\end{aligned}
$$

The Goodness of Fit (GoF) value can be searched using the formula:

$$
G o F=\sqrt{\overline{A V E} \times \overline{R^{2}}}
$$

By using the GoF formula above, a value of 0.593 (high category) is generated. According to Tenenhaus et al. (2004) the value of GoF ranges from $0-1$, where GoF values are small $=0.1-0.25, \mathrm{GoF}$ medium $=0.25-0.38$ and $\mathrm{GoF}$ high $=$ above 0.38 .

\section{Hypothesis Testing}

Hypothesis testing to see the relationship between parameters by looking at the $\mathrm{p}$-value. A p-value below 0.05 indicates a significant relationship. Hypothesis testing is done by bootstrapping shown in Figure 3. 


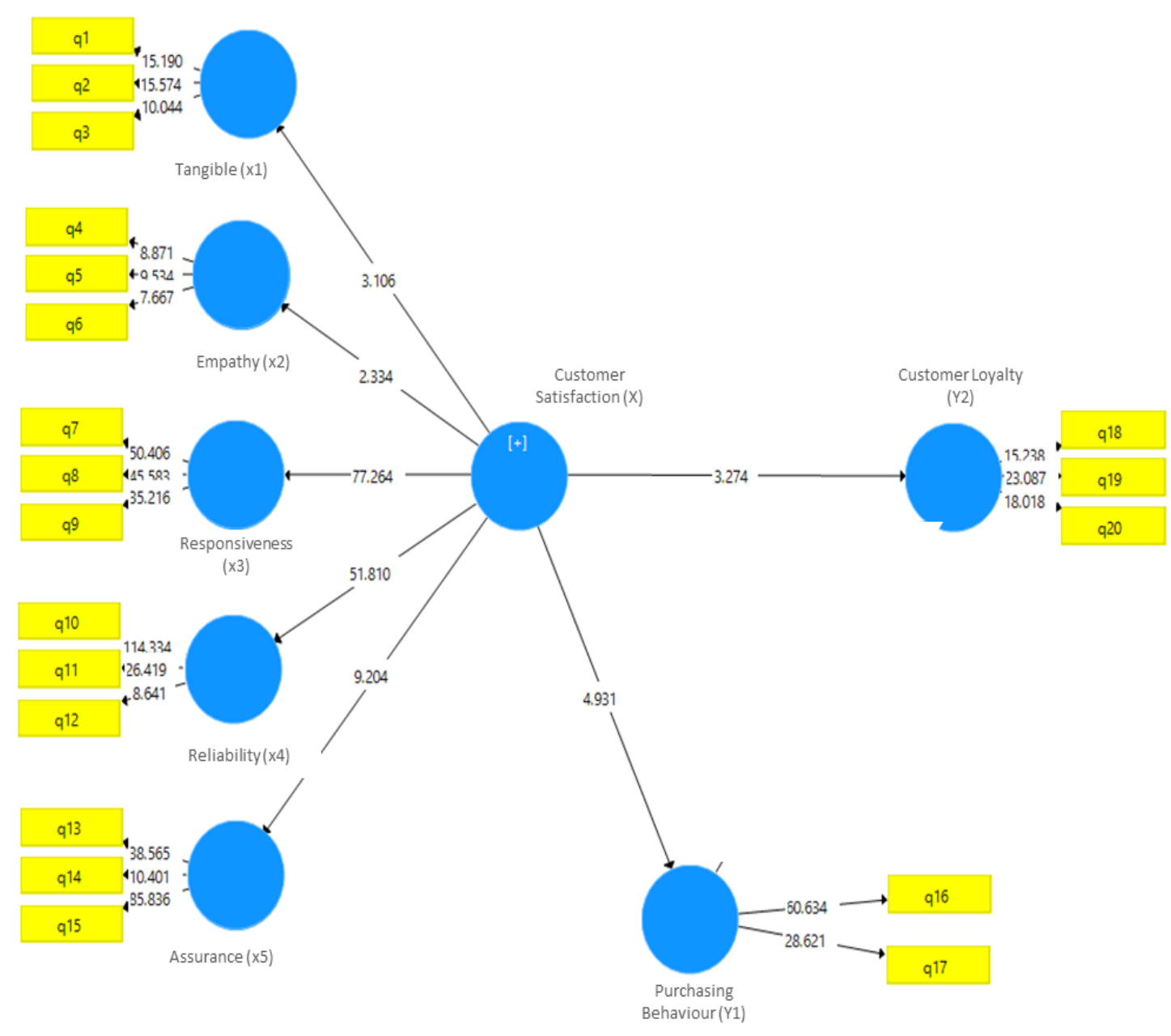

Figure 3 Bootstrapping

The results of the hypothesis testing can be explained in Table 5 below.

Table 5 Path coefficients

\begin{tabular}{lccccc}
\hline Variable & $\begin{array}{c}\text { Original Sample } \\
(\mathrm{O})\end{array}$ & $\begin{array}{c}\text { Sample Mean } \\
(\mathrm{M})\end{array}$ & $\begin{array}{c}\text { Standard Deviation } \\
(\text { STDEV })\end{array}$ & $\begin{array}{c}\text { T Statistics } \\
(\mathrm{O} / \text { STDEV })\end{array}$ & $\begin{array}{c}\mathrm{P} \\
\text { Values }\end{array}$ \\
\hline $\mathrm{X} \rightarrow \mathrm{x} 1$ & 0.221 & 0.221 & 0.068 & 3.233 & 0.001 \\
$\mathrm{X} \rightarrow \mathrm{x} 2$ & 0.162 & 0.177 & 0.065 & 2.506 & 0.013 \\
$\mathrm{X} \rightarrow \mathrm{x} 3$ & 0.924 & 0.924 & 0.012 & 77.282 & 0.000 \\
$\mathrm{X} \rightarrow \mathrm{x} 4$ & 0.852 & 0.855 & 0.015 & 57.292 & 0.000 \\
$\mathrm{X} \rightarrow \mathrm{x} 5$ & 0.494 & 0.504 & 0.054 & 9.09 & 0.000 \\
$\mathrm{X} \rightarrow \mathrm{y} 1$ & 0.306 & 0.313 & 0.061 & 5.05 & 0.000 \\
$\mathrm{X} \rightarrow \mathrm{y} 2$ & 0.223 & 0.229 & 0.067 & 3.327 & 0.001 \\
\hline
\end{tabular}

\section{Evaluation of the Effect of Service Quality on Customer Satisfaction}

All service dimensions consisting of Tangible, Empathy, Responsiveness, Reliability, and Assurance (TERRA) have a p-value below 0.05, which means that customer satisfaction is influenced by the TERRA dimension. From the correlation coefficient, it can be seen that the tangible (x1) dimension has a correlation of 0.221 , 
which means that customer satisfaction is reflected by 22.1 percents by the tangible service quality. Furthermore, the dimensions of empathy (x2) of 0.162 customer satisfaction is reflected by 16.1 percents by the service quality of empathy. The responsiveness dimension (x3) has a correlation of 0.924 , which means that customer satisfaction is reflected by 92.4 percents by the service quality dimension of responsiveness. Reliability dimension (z4) has a correlation of 0.852 which means that customer satisfaction is reflected by 85.2 percents by service quality reliability dimensions.

While the assurance dimension correlates 0.494 , which means that customer satisfaction is reflected by 49.4 percents by the quality of assurance services, it can be concluded that the parameters of customer satisfaction at PT Antam Tbk. LM is the highest reflected by the speed of CS officers and security officers in responding and serving customers (responsiveness). This means that these parameters need to be considered for increased satisfaction because they have the greatest influence on satisfaction. While based on the level of satisfaction, this responsiveness is still lower than reliability or assurance.

Responsiveness can be defined as a willingness to help, how to provide services that are fast and handle problems or complaints properly. In other words, responsiveness means being responsive to customer needs. As human nature is generally happy when observed, served quickly and assisted when experiencing problems, the responsiveness of service personnel becomes very important in serving customers.

\section{Evaluation of the Effect of Customer Satisfaction on Purchasing Behavior}

The effect of customer satisfaction (X) on purchasing behavior (Y1) is indicated by the p-value of $0.000(<0.05)$ which means there is an influence of customer satisfaction (X) on purchasing behavior (Y1). The relationship between satisfaction and buying behavior is positive, meaning that the more satisfied the customer, the higher the frequency of purchases made by customers, and the longer the customer becomes PT. Antam Tbk. LM.

When viewed from the effect, customer satisfaction has more influence on the frequency of purchases (0.932) compared to the length of time being a customer (0.892). Consumers who are satisfied with the services at LM Pulogadung's Gold Boutique tend to purchase transactions more often.

\section{Evaluation of the Effect of Customer Satisfaction on Customer Loyalty}

The effect of customer satisfaction (x) on customer loyalty (y2) is indicated by the $\mathrm{p}$-value of $0.001(<0.05)$, meaning that customer satisfaction $(\mathrm{x})$ affects customer loyalty (Y2). The results of this study reinforce the results of previous studies, as conducted by Rust et al. (1995); Storbacka et al. (1994); Annisa (2014); Panjaitan (2016); that customer satisfaction has a significant influence on customer loyalty. This also happened to BELM Pulogadung consumers, where customers who were satisfied with the quality of service available at BELM Pulogadung made them loyal shown by repurchasing, still buying at BELM Pulogadung and willing to recommend to other people. The biggest influence is to keep buying at BELM. This means that the responsiveness of services available at BELM Pulogadung can be a differentiator with gold buying services elsewhere. 


\section{Discussion and Managerial Implication}

The Managerial implication on this study as a form of marketing strategy that can be done to increase customer satisfaction and loyalty is to maintain service quality on the dimension of Responsiveness through implementation strategies of Standard Level Agreement (SLA) which is a reference or formulation of the time limit in providing the best services. In terms of speed of service and responsiveness to customer needs, it needs to be a priority to note. If it is associated with the marketing mix, the aspects of people are the most influential aspects of customer satisfaction and loyalty. Murpraptomo et al. (2019) examining the marketing mix and satisfaction affects word of mouth. People who interact directly with consumers in providing services are an important part of establishing loyalty. The knowledge and ability of people who serve is a very important key message to achieve success. For this reason, it is necessary to place front-liners who can provide services quickly, precisely, and friendly under predetermined service standards.

\section{Conclusion}

\section{Conclusion and Recommendation}

The behavior of BELM customers in the Pulogadung branch purchase more gold twice a year for investment. The majority of ANTAM's customers are old customers for more than one year. BELM Pulogadung's customer satisfaction level is 4.29, which means that customers are satisfied with the service at BELM Pulogadung. The satisfaction level of each dimension is Tangible 4.18, Empathy 4.32, Responsiveness 4.24, Reliability 4.36, Assurance 4.35. Service quality factors that influence customer satisfaction can be seen from the correlation coefficients of each dimension, such as Tangible 0.221, Empathy 0.162, Responsiveness 0.924, Reliability 0.852, and Assurance 0.494. The highest quality factor of service influence on customer satisfaction is Responsiveness, such as the speed of CS officers and security officers in responding and serving customers and information clarity. Customer satisfaction affects customer loyalty and purchasing behavior.

\section{Recommendation}

From the results of measurements of satisfaction seen in terms of entertainment facilities at BELM, satisfaction is not as high as other aspects. For this reason, it is necessary to equip boutiques with entertainment facilities for customers while waiting for the queue of transactions and if necessary create uniformity for all UBPP LM's gold boutiques (BELM). For further research to be able to see the effect of customer characteristics on purchasing decisions to segment consumers. By classifying or segmenting consumers appropriately, the company can maintain and increase the level of sales and more importantly so that the company's operations in the long term can be sustainable and competitive (Porter, 1991). Consumer segmentation was also examined by Aviliani et al. (2011). By combining segmentation, demographic profiles, and transaction profiles, BRI will obtain more precise target customers and be able to allocate resources for marketing strategies more effectively. 


\section{References}

Akhtar, A., \& Zaheer, A. (2014). Service quality dimensions of Islamic banks: a scale development approach. Global Journal of Management and Business Research, 14(5), 10-20.

Anita. (2015). Analisis komparasi investasi logam mulia emas dengan saham perusahaan pertambangan di Bursa Efek Indonesia 2010-2014. Jurnal Bisnis dan Manajemen, 5(2), 243-252. doi: 10.15408/ess.v5i2.2346.

Annisa, A. R. (2014). Pengaruh kualitas pelayanan jasa verifikasi impor terhadap kepuasan dan loyalitas pelanggan PT Surveyor Indonesia (Persero). Jurnal Aplikasi Manajemen, 12(1), 1-9.

Arthur, K. M., Asmara, A., \& Simanjuntak, M. (2019). The effect of marketing mix on "KPR Xtra Bebas" decision making in bank x regional. Journal of Consumer Sciences, 4(1), 1-12.

Aviliani, Sumarwan, U., Sugema, I., \& Saefuddin, A. (2011). Segmentasi nasabah tabungan mikro berdasarkan recency, frequency, dan monetary: kasus Bank BRI. Finance and Banking Journal, 13(1), 95-109.

Bakhtiar, A., Susanty, A., \& Massay, F. (2010). Analisis kualitas pelayanan yang berpengaruh terhadap kepuasan pelanggan menggunakan metode servqual dan model kano (studi kasus: PT. PLN UPJ Semarang Selatan). J@ti Undip: Jurnal Teknik Industri Undip, 2, 77-80. doi: https://doi.org/10.12777/jati.5.2.77-84.

Baur, D. G., \& Lucey, B. M. (2010). Flights and contagion - an empirical analysis of stock-bond correlations. Journal of Financial Stability, 5(4), 339 - 352. doi:10.1016/j.jfs.2008.08.001.

Chin, W. W. (1998). Issues and opinion on structural equation model. Journal of MIS Quarterly, 22(1), 7-16.

Dewi, N. A., Rahmawati, R., \& Mukid, M. A. (2015). Analisis kepuasan pengunjung menggunakan second order confirmatory factor analysis pada structural equation modeling (studi kasus: pengunjung pemandian air panas (PAP) Guci). Jurnal Gaussian, 4(1), 83-92.

Djamaluddin, M. D., Sumarwan, U., \& Mahardikawati, N. G. (2009). Analisis kepuasan dan loyalitas konsumen jamu gendong di Kota Sukabumi. Jurnal Ilmiah Keluarga dan Konsumen, 2(2), 174-184. doi: http://dx.doi.org/10.24156/jikk.2009.2.2.174.

Ghozali, I. (2008). Structural Equation Modelling. (Ed 2). Semarang: Universitas Diponegoro.

Gunawan, A. I,. \& Wirawati, N. G. P. (2013). Perbandingan berinvestasi antara logam mulia emas dengan saham perusahaan pertambangan emas. E-Jurnal Akuntansi Universitas Udayana, 4(2), 406-420.

Hallowell, R. (1996). The relationships of customer satisfaction, customer loyalty, and profitability: an empirical study. International Journal of Service Industry Management, 7(4), 27-42. doi: https://doi.org/10.1108/09564239610129931

Handoyo, I. G. S. R., \& Setiawan, P.Y. (2015). Pengaruh karakteristik demografi dan ketidakpuasan terhadap perilaku mengeluh konsumen pada bengkel service sepeda motor Yamaha Diponegoro Denpasar Bali. E-Jurnal Manajemen Unud,4(10), 3317 -3345 .

Heviandri, R., Sumarwan, U., \& Retnaningsih. (2009). Analisis kepuasan konsumen 
terhadap layanan di Bandara Soekarno-Hatta, serta implikasinya terhadap strategi pemasaran City Check-In Terminal di Jakarta. Jurnal Manajemen dan Agribisnis, 6(2), 124-13. doi: http://dx.doi.org/10.17358/jma.6.2.124-139.

Kotler, P., \& Keller, K.L. (2012). Manajemen pemasaran. (Ed 12). Jakarta: Erlangga.

Manalu, A.S.B., Sumarwan, U., \& Suroso, A.I. (2007). Anaisis faktor-faktor yang mempengaruhi kepuasan pelanggan online. Jurnal Manajemen dan Agribisnis, 4(2), 67-80. doi: http://dx.doi.org/10.17358/jma.4.2.67-80.

Mardatilla, R., Kusyanti, A., \& Aryadita, H. (2017). Pengaruh kualitas layanan terhadap kepuasan, kepercayaan dan loyalitas pelanggan pada e-commerce (studi kasus: Berrybenka). Jurnal Pengembangan Teknologi Informasi dan Ilmu Komputer, 1(12), 1822-1832.

Moosa, I. A. (2007). Foreign Direct Investment: Theory, evidence, and practice. United Kingdom: Palgrave Macmillan.

Murpraptomo, S. H., Yulianti, L. N., \& Sartono, B. (2019). The influence of marketing mix, perceived risk, and satisfaction on word of mouth in XYZ clinic. Journal of Consumer Sciences, 4(1), 13-24.

Nelson, E. C., Rust, R. T., Zahorik, A., Rose, R.L., Batalden, P., \& Siemanski, B. A. (1992). Do patient perceptions of quality relate to hospital financial performance. Journal of Health Care Marketing, 12(4), 6-13.

Nugraheni, R., \& Kirana, G.R. (2018). The analysis quality of service and patient satisfaction participants of health BPJS in interior services in hospital X of Kediri City. Journal of Global Research in Public Health, 3(1), 9-17. doi: W: http://ojs.stikesstrada.ac.id/index.php/JGRPH.

Panjaitan, J. E. (2016). Pengaruh kualitas pelayanan terhadap kepuasan pelanggan pada JNE cabang Bandung. DeReMa Jurnal Manajemen, 11(2), 265-289.

Porter, M. E. (1991). Towards a dynamic theory of strategy. Strategic Management Journal, 12, 95-117. doi: https://doi.org/10.1002/smj.4250121008.

Purwanti, N. D., Sugiono, \& Hardiningtyas, D. (2015). Analisis pengaruh kualitas pelayanan dan citra perusahaan terhadap kepuasan dan loyalitas pelanggan (studi kasus: PT. PLN (Persero) Rayon Malang Kota). Jurnal Rekayasa dan Manajemen Sistem Industri, 3(2), 244-255.

Riyadi, S., Hermawan, A., \& Sumarwan, U. (2015). Kepuasan masyarakat terhadap kualitas pelayanan kantor pertanahan Kabupaten Indramayu. Jurnal Ilmu Keluarga dan Konsumen, 8(1), 49-58. doi: http://dx.doi.org/10.24156/jikk.2015.8.1.49.

Rizq, S., Djamaludin, M.D., \& Nurhadryani, Y. (2018). Analysis of service quality satisfaction of e-ktp service at public administration and civil registration office of Bogor district. Journal of Consumer Sciences, 3(2), 55-65.

Rust, R.T., Zahorik, A.J., \& Keiningham, T.L. (1995). Return on quality (RoQ): making service quality financially accountable. Journal of Marketing, 59(2), 58-70. doi: 10.2307/1252073.

Storbacka, K., Strandvik,T., \& Grönroos, C. (1994). Managing customer relationships for profit: the dynamics of relationship quality. International Journal of Service Industry Management, 5(5), 21-38. doi: https://doi.org/10.1108/09564239410074358

Sumarwan, U. (2011). Perilaku konsumen: teori dan penerapannya dalam pemasaran. (2nd Ed). Bogor, Indonesia: Ghalia Indonesia.

Sumarwan, U. (2014). Metode Riset Bisnis dan Konsumen. Bogor, Indonesia: IPB Press.

Susila, B., Sumarwan, U., \& Kirbrandoko. (2014). Analisis kepuasan konsumen 
terhadap brand awitching behavior minuman teh dalam kemasan. Jurnal Ilmu Keluarga dan Konsumen, 7(3), 193-201. doi: http://dx.doi.org/10.24156/jikk.2014.7.3.193.

Tenenhaus, M., Amato, S., \& Vinzi, V.E. (2004). A global goodness-of-fit index for PLS structural equation modeling. In: Proceedings of the XLII SIS scientific meeting. 739-742.

Tyson, E. (2011). Investing for Dummies. (6th Ed). Hoboken, NJ: John Wiley \& Sons. Hoboken.

Zeithaml, V.A., Parasuraman, A., Berry, L.L. (1990). Delivering quality service: balancing customer perceptions and expectations. New York, United States: The Free Press. Mac Millan Inc. 